\title{
KOMPARASI MODEL INKUIRI TERBIMBING MENGGUNAKAN \\ EKSPERIMEN LABORATORIUM RIIL DAN VIRTUAL TERHADAP KETERAMPILAN PROSES SAINS SISWA
}

\author{
Astri Liliana Sari' ${ }^{1)}$, Elvi Yenti ${ }^{2}$ \\ ${ }^{1}$ Program Studi Pendidikan Kimia, Universitas Islam Negeri Sultan Syarif Kasim Riau \\ Email: astrililianasari@gmail.com \\ ${ }^{2}$ Program Studi Pendidikan Kimia, Universitas Islam Negeri Sultan Syarif Kasim Riau \\ Email: elviyenti10@gmail.com
}

\begin{abstract}
This research was an experiment aiming at knowing the difference between the effect of Guided Inquiry model using Real and Virtual Laboratory Experiment on student science processes skill on Buffer material at State Senior High School Plus Riau Province in the Academic Year of 2016/2017. Samples of this research were the elevent grade student class MS 1 as the first experimental group amount 25 students taught by using Guided Inquiry model usig Real Laboratory Experiment and class MS 4 as the second experimental group amount 25 students taught by using Guided Inquiry Model using Virtual Laboratory Experiment. Simple random sampling was used in this research. Documentation and observation were the techniques of collecting the data. The preliminary and final data were analyzed by using Independent sample ttest. Based on the result the data processed, it was obtained that $t_{\text {observed }}$ was 2.432 and $t_{\text {tabel }}$ was 1.671 revealing that $t_{\text {observed }}$ was was higher than $t_{\text {tabel. }}$ Thus $H_{o}$ was rejected. This research finding revealed that the use of Guided Inquiry model using Real and Virtual Laboratory Experiment on Buffer material. Kp formula was used to measure the effect of using Guided Inquiry model, and the coefficient effect was $10.96 \%$.
\end{abstract}

Keywords: Guided Inquiry Model, Real Laboratory, Virtual Laboratory, Science Processes Skill, Buffer

\section{PENDAHULUAN}

Pembelajaran memiliki peranan penting dalam proses pendidikan. Dimana pembelajaran itu tidak hanya ditekankan pada penguasaan materi, tetapi juga ditekankan pada penguasaan keterampilan. Siswa juga harus memiliki kemampuan untuk berbuat sesuatu dengan menggunakan proses dan prinsip keilmuan yang telah dikuasai, seperti learning to know (pembelajaran untuk tahu) dan learning to do (pembelajaran untuk berbuat), hal ini harus dicapai dalam kegiatan belajar mengajar terutama pada pembelajaran sains [1]. Untuk mencapai pembelajaran itu semua maka keterampilan proses sains perlu dilakukan. Keterampilan proses sains perlu dikembangkan karena di dalamnya terdapat keterampilan kognitif, manual, dan sosial. Keterampilan proses sains juga merupakan salah satu faktor yang dapat menentukan proses belajar khusunya pada mata pelajaran kimia [1].

Mata pelajaran kimia menekankan pada pemberian pengalaman belajar secara langsung melalui penggunaan dan pengembangan keterampilan proses dan sikap ilmiah. Oleh karena itu, mata pelajaran kimia diharapkan dapat memudahkan siswa dalam memahami konsep, prinsip, hukum dan teori kimia serta saling keterkaitannya dan penerapannya untuk menyelesaikan masalah dalam kehidupan sehari-hari dan teknologi. Salah satunya adalah materi pokok larutan penyangga, materi ini merupakan materi konsep yang tidak hanya sekedar dihafalkan tetapi memerlukan suatu pengeksplorasian melalui kegiatan praktikum yang dapat melatih siswa untuk mencari dan melakukan suatu penyelidikan secara sistematis sehingga siswa dapat merumuskan 
sendiri konsep pada materi yang sedang dipelajari [2]. Dalam hal ini praktek laboratorium dan eksperimen dalam pembelajaran diharapkan harus dapat membantu siswa untuk memperoleh kemampuan teknis [3].

Namun, saat ini kendala utama yang dihadapai oleh sebagian besar sekolah di tingkat SMA adalah minimnya sarana dan prasarana laboratorium baik dari segi alat maupun bahan kimia yang tersedia [4]. Serta waktu praktikum yang terbatas membuat praktikum sulit dilakukan selama proses pembelajaran. Dan kendala utama yang dialami selama proses belajar mengajar antara guru dan siswa adalah guru cenderung memberi materi kepada siswa sebagai produk daripada sebagai proses. Hal ini membuat banyak siswa yang kurang berperan dalam memaksimalkan keterampilan proses sains yang dimilikinya.

Berdasarkan data awal yang diperoleh peneliti dari guru kimia kelas XI SMA Negeri Plus Provinsi Riau yang berupa dokumentasi dan wawancara, dan observasi awal peneliti mendapatkan data bahwa selama dua tahun terakhir pada materi larutan penyangga ada beberapa faktor yang membuat keterampilan proses sains siswa rendah terutama pada praktikum di sekolah. Pertama, siswa kurang aktif dan kaku dalam menggunaan alat, hal ini terlihat siswa sering salah dalam menyebut nama alat dan menggunakan alat tidak sesuai fungsinya. Kedua, siswa kurang dalam pemahaman konsep kimia sebagai proses, hal ini terlihat siswa sering sekali bertanya kepada guru setiap langkah-langkah kegiatan praktikum. Ketiga, selama proses praktikum model pembelajaran yang digunakan berupa discovery learning. Discovery learning merupakan model pembelajaran yang memang digunakan pada pembelajaran kurikulum 2013, kelebihan pada model discovery learning ini adalah untuk mengembangkan pemahaman, namun untuk mengembangkan aspek konsep, keterampilan dan emosi secara keseluruhan kurang mendapat perhatian [5].
Alternatif pembelajaran yang berpotensi dapat menyelesaikan permasalahan keterampilan proses sains adalah inkuiri. Model pembelajaran inkuiri terbimbing mampu mengembangkan keterampilan proses sains siswa baik pada berkemampuan akademik tinggi, sedang, dan rendah serta dapat melibatkan keaktifan siswa dalam proses pembelajaran [6]. Model pembelajaran inkuiri terbimbing sangat sesuai untuk mengembangkan keterampilan proses sains, karena sintak atau tahap pembelajaran di dalam inkuiri terbimbing yang dikembangkan dengan metode ilmiah dapat melatihkan keterampilan proses sains pada siswa [7]. Proses pembelajaran ini sangat cocok untuk dilakukan pada eksperimen riil maupun laboratorium virtual.

Berdasarkan paparan di atas maka yang menjadi tujuan dalam penelitian ini adalah menganalisa perbedaan keterampilan proses sains siswa terhadap penggunaan model inkuiri terbimbing yang dilengkapi eksperiment laboratorium riil dengan pengaruh penggunaan model inkuiri terbimbing yang dilengkapi ekseprimen virtual.

\section{METODE PENELITIAN}

Penelitian ini merupakan penelitian eksperimen yang dilakukan terhadap dua kelas, yaitu kelas eksperimen I dan kelas eksperimen II. Di dalam penelitian ini, pada kelas eksperimen I diberikan perlakuan menggunakan model pembelajaran inkuiri terbimbing dilengkapi eksperimen laboratorium riil sedangkan pada kelas eksperimen II diberikan perlakuan menggunakan model pembelajaran inkuiri terbimbing dilengkapi eksperimen laboratorium virtual. Subjek penelitian ini adalah siswa kelas XI SMA Negeri Plus Provinsi Riau tahun ajaran 2016/2017 dan objek pada penelitian ini adalah keterampilan proses sains siswa pada pelajaran kimia pokok bahasan larutan penyangga. Variabel terikat pada penelitian ini adalah keterampilan proses sains siswa sedangkan variabel bebasnya adalah model inkuiri terbimbing menggunakan eskperimen 
laboratorium riil dan virtual. Pengumpulan data menggunakan dokumentasi dan lembar observasi. Sedangkan teknik analisis data menggunakan uji homogenitas dengan uji Barlett, uji normalitas dengan Chi Kuadrat, analisis data observasi dan uji t komparasi independen.

\section{HASIL DAN PEMBAHASAN}

Dalam penelitian ini dibutuhkan dua sampel yang memiliki kemampuan homogen. Oleh karena itu, perlu dilakukan tes uji homogenitas dengan memberikan soal kepada keempat kelas yaitu kelas XI MS 1, kelas XI MS 2, kelas XI MS 3, dan kelas XI MS 4. Dari keempat kelas tersebut hasil tes uji homogenitas dihitung menggunakan metode bartlet. Hasil analisis untuk uji homogenitas dengan metode bartlet didapatkan bahwa nilai $\chi^{2}{ }_{\text {hitung }}=0,081$ dan nilai $\chi_{\text {tabel }}^{2}=7,815$ dan didapat bahwa $\chi^{2}{ }_{\text {hitung }}<\chi^{2}$ tabel. Hal ini berarti keempat sampel mempunyai varians yang sama (homogen).

Setelah keempat kelas homogen, peneliti menggunakan simple random sampling. Dimana simple random sampling memberikan peluang yang sama bagi setiap anggota populasi untuk dipilih sebagai anggota sampel. Dan terpilihlah kelas eksperimen 1 adalah kelas XI MS 1 sedangkan kelas eksperimen II adalah kelas XI MS 4.

Instrumen dalam penelitian ini adalah lembar observasi yang digunakan untuk mengamati keterampilan proses sains siswa yang terdiri dari 8 aspek keterampilan proses sains dengan 13 indikator. Sebelum digunakan sebagai instrumen dalam penelitian ini, lembar observasi diuji cobakan terlebih dahulu kepada salah satu kelas dengan jumlah siswa sebanyak 25 orang pada saat praktikum dilakukan. Hasil uji coba soal kemudian dianalisis untuk mengetahui validitas dan reliabilitasnya.

Hasil analisis validitas isi yang telah dilakukan diperoleh 13 indikator yang valid karena semua indikator sesuai dengan aspek keterampilan proses sains siswa yang akan diteliti, sehingga seluruh indikator lembar observasi tersebut dinyatakan valid.

Hasil uji coba validitas empiris dengan menggunakan rumus korelasi product moment diperoleh 10 indikator yang valid dan 3 indikator yang tidak valid.

Dengan demikian dari 8 aspek KPS dengan 13 indikator keterampilan proses sains siswa hanya 6 aspek KPS dengan 10 indikator yang dapat dilanjutkan untuk menjadi rubrik keterampilan proses sains. Adapun diagram persentase validitas empiris dari indikator KPS dapat dilihat pada gambar I berikut.

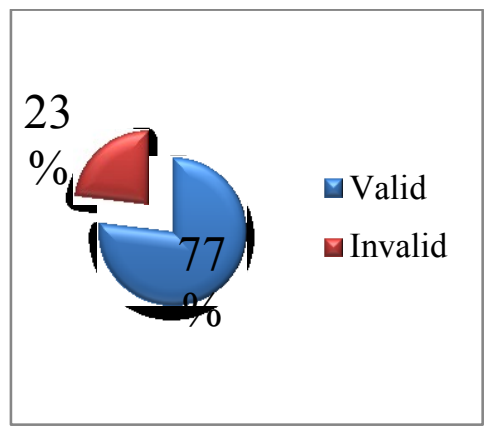

Gambar I Diagram Uji Validitas Empiris

Berdasarkan hasil analisis lembar observasi yang telah dilakukan dengan menggunakan rumus Alpha Croncbach, maka diperoleh reliabilitas sebesar 0,78 dengan kriteria tinggi.

Analisis data dilakukan dengan menggunakan uji-t komparasi dua sampel independen. Namun penggunaan uji-t tersebut harus memenuhi dua syarat yaitu:

\section{Uji Homogenitas Akhir}

Data yang digunakan untuk uji homogenitas adalah rata-rata hasil observasi dari kedua kelas yaitu kelas eksperimen I dan II. Data yang diperoleh dari lembar observasi adalah data ordinal, sehingga data yang ada harus diubah menjadi data interval sebelum data diuji dengan uji-t. Hasil pengujian homogenitas dari observasi akhir untuk kelas eksperimen I dan II terangkum dalam tabel I berikut: 


\begin{tabular}{cccccc}
\hline \multicolumn{6}{l}{ Tabel I Hasil Analisis Data Uji } \\
Homogenitas Akhir \\
\begin{tabular}{cccccc} 
Kelas & $\mathbf{n}$ & $\overline{\mathbf{X}}$ & $\mathbf{S}_{\mathbf{i}}^{\mathbf{2}}$ & $\begin{array}{c}\mathbf{F} \\
\text { hit }\end{array}$ & $\begin{array}{c}\mathbf{F} \\
\text { tabel }\end{array}$ \\
\hline Ekp I & 25 & 44,2 & 75,3 & 1, & 1,9 \\
Ekp II & 25 & 50,3 & 84,1 & 12 & 8 \\
\hline
\end{tabular}
\end{tabular}

Taraf signifikan $(\alpha)=0,05$, maka dicari pada Tabel $\mathrm{F}$ didapat $\mathrm{F}_{\text {tabel }}=1,98$. Berdasarkan data dapat dilihat $\mathrm{F}_{\text {hitung }}<\mathrm{F}_{\text {tabel, }}$ atau $1,12<1,98$ maka varians-varians adalah Homogen (perhitungan data lamp. W).

\section{Uji Normalitas}

Hasil uji normalitas terangkum dalam tabel II berikut:

Tabel 11 Hasil Analisis Data Uji

\section{Normalitas}

\begin{tabular}{cccc}
\hline Kelas & $\boldsymbol{\chi}^{\mathbf{2}}$ hitung & $\boldsymbol{\chi}^{2}$ tabel & Kriteria \\
\hline Eksp I & 8,892 & 11,070 & Normal \\
Eksp II & 1,755 & 11,070 & Normal \\
\hline
\end{tabular}

Berdasarkan hasil penelitian dapat diamati bahwa nilai $\chi^{2}$ hitung kelas eksperimen I sebesar 8,892 sedangkan untuk nilai $\chi^{2}{ }_{\text {hitung }}$ kelas eskperimen II sebesar 1,755. Harga $\chi_{\text {tabel }}^{2}$ kelas eksperimen I dan kelas eksperimen II untuk $\alpha=0,05$ adalah sebesar 11,070 (perhitungan data lamp. $\mathrm{X}_{1}$ dan $\mathrm{X}_{2}$ ).

Kriteria pengujian: Jika $\chi^{2}$ hitung $\geq \chi^{2}$ tabel, Distribusi Data Tidak Normal

Jika $\chi^{2}$ hitung $\leq \chi^{2}$ tabel, Data Berdistribusi Normal.

Dengan demikian maka dapat dikatakan bahwa data terdistribusi normal.

Setelah dilakukan uji homogenitas dan uji normalitas, data hasil penelitian menunjukkan homogen dan normal. Karena varians homogen $\left(n_{1}=n_{2}\right)$, maka rumus uji-t komparasi independen yang digunakan adalah dengan polled varians. Karena penelitian ini dilakukan untuk melihat perbandingan antara dua kelas yang tidak berhubungan. Untuk mengetahui $t_{\text {tabel }}$ digunakan $\mathrm{dk}=\mathrm{n}_{1}+\mathrm{n}_{2}-2$. Hasil uji-t terangkum dalam tabel III berikut:
Tabel III Hasil Analisis Data Uji t-test

Komparasi Independen

\begin{tabular}{cccccc}
\hline Kelas & $\mathbf{N}$ & Varians & $\overline{\boldsymbol{X}}$ & $\begin{array}{c}\mathbf{t} \\
\text { hitung }\end{array}$ & $\mathbf{t}_{\text {tabel }}$ \\
\hline Ek I & 25 & 84,04 & 44,23 & 2,432 & 1,671 \\
Ek II & 25 & 75,38 & 50,36 & & \\
\hline
\end{tabular}

Berdasarkan tabel diatas dapat dilihat bahwa nilai $t_{\text {hitung }}=2,432$ dan $t_{\text {tabel }}=1,671$ sehingga $t_{\text {hitung }}>t_{\text {tabel }}$. Maka hipotesisnya diterima yaitu ada perbedaan pengaruh dari penggunaan model inkuiri terbimbing menggunakan eksperimen laboratorium riil dengan penggunaan model inkuiri terbimbing menggunakan eksperimen laboratorium virtual terhadap keterampilan proses sains siswa di kelas XI pada materi Larutan Penyangga.

Untuk harga koefisien korelasi $\left(\mathrm{r}^{2}\right)=$ 0,1036 dan koefisien pengaruh $(\mathrm{Kp})=10,96$ $\%$. Oleh karena itu, berdasarkan nilai $\mathrm{Kp}$ tersebut maka pada penelitian ini terdapat pengaruh model inkuiri terbimbing baik menggunakan laboratorium riil maupun virtual terhadap keterampilan proses sains siswa sebesar $10,96 \%$.

Instrument yang sudah valid dan reliabel dapat digunakan untuk menganalisa perbedaan model inkuiri terbimbing menggunakan laboratorium riil dengan model inkuiri terbimbing menggunakan laboratorium virtual.

Data yang diperoleh merupakan data keterampilan proses sains siswa (KPS) melalui lembar observasi. Data KPS siswa diperoleh dari observasi pada kelas eksperimen I (kelas XI MS 1) dan kelas eksperimen II (kelas XI MS 4). Kelas eksperimen I menerapkan model inkuiri terbimbing menggunakan laboratorium riil dan eksperimen II menerapkan model inkuiri terbimbing menggunakan laboratorium virtual. Terdapat 6 aspek keterampilan proses sains yang diamati yaitu mengamati, berhipotesis, merancang percobaan, menggunakan alat dan bahan, menafsirkan/interpretasi data dan menerapkan konsep dengan 10 indikator. Adapun perbandingan keterampilan proses 
sains siswa kelas eksperimen I dan II disajikan pada gambar 2 berikut.

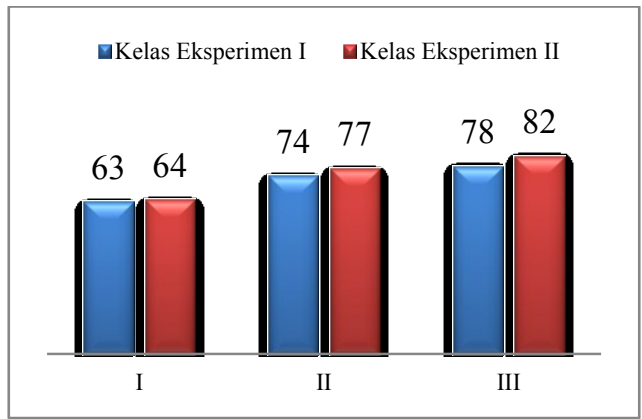

\section{Gambar 2. Perbandingan KPS Siswa di Kelas Eksperimen I dan II Tiap Pertemuan}

Dari gambar 2 secara keseluruhan dapat dibandingkan KPS siswa kelas eksperimen II lebih tinggi daripada KPS siswa kelas eksperimen I. Pada pertemuan pertama, persentase KPS siswa pada kelas eksperimen I sebesar 63\% sedangkan pada kelas eksperimen II adalah 64\%. Pada pertemuan kedua, persentase KPS siswa pada kelas eksperimen I sebesar $74 \%$ sedangkan pada kelas eksperimen II sebesar 77\%. Pada pertemuan ketiga, persentase KPS siswa pada kelas eksperimen I sebesar 78\% sedangkan pada kelas eksperimen II adalah $82 \%$.

Data KPS siswa diperoleh dari observasi pada kelas eksperimen I (kelas XI MS 1) dan kelas eksperimen II (kelas XI MS 4). Subjek yang diamati sebanyak 25 orang siswa dan terdapat 6 aspek keterampilan proses sains dengan 10 indikator yang diamati yaitu mengamati, berhipotesis, merancang percobaan, menggunakan alat dan bahan, menafsirkan/interpretasi data dan menerapkan konsep. Hasil observasi dilihat berdasarkan observasi pertemuan pertama sampai pertemuan ketiga. Sedangkan perbandingan hasil observasi keterampilan proses sains siswa tiap indikator dijelaskan pada gambar 3 berikut.

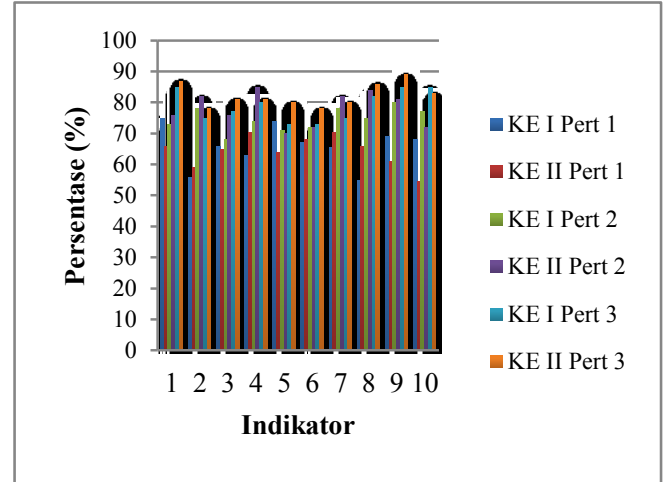

Gambar 3. Perbandingan KPS di Kelas Eksperimen I dan II Pada Setiap Indikator

Berdasarkan dari hasil analisis statistik dari rata-rata keterampilan proses sains siswa selama tiga kali pertemuan dan uji hipotesis menggunakan uji t komparasi independen, diperoleh nilai $t_{\text {hitung }}>t_{\text {tabel }}(2,432>1,671)$ pada taraf signifikan $5 \%$, diperoleh kesimpulan bahwa hipotesis Ho ditolak dan Ha diterima.

Dengan demikian, hasil analisis ini mendukung hipotesis yang diajukan yaitu ada perbedaan pengaruh dari penggunaan model inkuiri terbimbing menggunakan eksperimen laboratorium riil dengan penggunaan model inkuiri terbimbing menggunakan eksperimen laboratorium virtual terhadap keterampilan proses sains siswa di kelas XI pada materi larutan penyangga di SMA Negeri Plus Provinsi Riau.

Adapun perbandingan keterampilan proses sains siswa antara kelas eksperimen I dengan kelas eksperimen II dapat dilihat pada gambar 4 berikut ini:

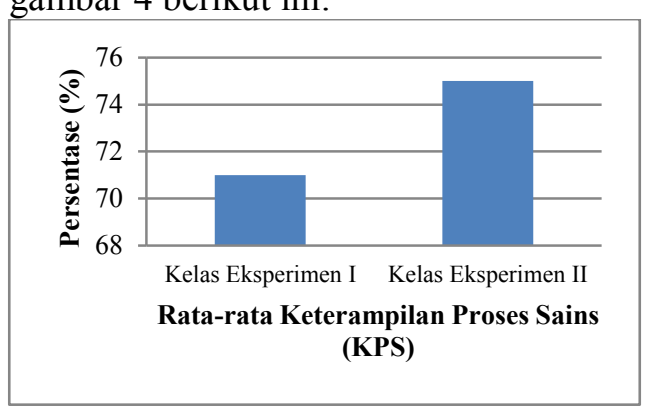

Gambar 4. Perbandingan Rata-rata Keterampilan Proses Sains Siswa di Kelas Eksperimen I dan II 
Dari data yang diperoleh dari lembar observasi dan rata-rata KPS siswa, terlihat bahwa siswa kelas eksperimen II memiliki keterampilan proses sains yang lebih baik dibandingkan kelas eksperimen I. Keterampilan proses sains siswa di kelas eksperimen I sebesar 71\% sedangkan di kelas eksperimen II sebesar 75\% keduanya memiliki interpretasi tinggi. Rentang rata-rata keterampilan proses sains siswa di kelas eksperimen I dan rata-rata keterampilan proses sains siswa di kelas eksperimen II sebesar 4\%. Maka dapat disimpulkan bahwa eksperimen dengan laboratorium virtual lebih baik dibandingkan dengan eksperimen laboratorium riil baik dari segi kognitif maupun psikomotorik pada siswa kelas XI SMA Negeri Plus Provinsi Riau.

Hal ini didukung oleh penelitian Septi Aprilia yang menyatakan bahwa prestasi kognitif siswa yang menggunakan media laboratorium virtual lebih baik daripada siswa yang menggunakan laboratorium riil. [8] Dimana siswa yang menggunakan laboratorium riil masih banyak terdapat kendala teknis yang menghambat proses percobaan, siswa masih banyak yang belum memahami cara menggunakan alat-alat laboratorium dengan benar sehingga mengakibatkan hasil percobaan menjadi tidak akurat dan waktu .

percobaan menjadi lebih lama. Sementara, siswa yang menggunakan laboratorium virtual tidak ditemui kendala teknis karena semua siswa sudah mempunyai basic pengoperasian komputer dengan baik, selain itu siswa dapat melakukan percobaan berulang-ulang sampai merasa paham tanpa menghabiskan waktu untuk mempersiapkan pengulangan. Pada dasarnya laboratorium riil dapat meningkatkan keterampilan proses sains siswa lebih baik daripada laboratorium virtual. Hal ini dikarenakan pada laboratorium riil, siswa dapat mengembangkan kemampuan menemukan masalah, mencari alternatif pemecahan masalah, membuat hipotesis, merancang penelitian atau percobaan, mengendalikan variabel, melakukan pengukuran, mengorganisasi dan memaknakan data, membuat kesimpulan, dan mengomunikasikan hasil penelitian atau percobaan baik secara lisan maupun tertulis. Selain itu dapat meningkatkan keterampilan atau psikomotoriknya, misalnya belajar memasang, menggunakan, merakit instrumen praktikum langsung serta mereka dapat melibatkan semua inderanya seperti indera penglihatan, pendengaran, perasaan, penciuman, dan peraba dimana hal ini tidak dapat ditemukan pada laboratorium virtual [9] Hal ini sesuai dengan penelitian yang dilakukan oleh Artha.(2009), dimana hasil belajar siswa pada media laboratorium riil lebih tinggi dari pada laboratorium virtual. Hal ini pun diperkuat oleh kerucut pengalaman Edgar Dale yang mengatakan hasil belajar seseorang atau siswa itu paling besar pada tingkat bermain peran, bersimulasi, melakukan hal nyata $(90 \%)$. [9]

Dapat diketahui bahwa keterampilan proses sains siswa (KPS) ketika diterapkan model inkuiri terbimbing menjadi lebih baik ketika menggunakan eksperimen laboratorium riil maupun laboratorium virtual. Hal ini dikarenkan penerapan model inkuiri terbimbing memiliki pengaruh dalam keterampilan proses sains siswa dan juga langkah belajar yang sejalan dengan aspek aspek keterampilan proses sains siswa. Sesuai dengan penelitian Idhun Prasetyo dkk yang mengatakan bahwa alternatif pembelajaran yang berpotensi dapat menyelesaikan permasalahan keterampilan proses sains adalah inkuiri. Inkuiri terbimbing cocok diterapkan di SMA karena sesuai dengan karakteristik siswa SMA yang cenderung kurang mandiri dan masih membutuhkan saran dan isyarat dari guru. Model pembelajaran inkuiri terbimbing mampu mengembangkan keterampilan proses sains siswa baik pada berkemampuan akademik tinggi, sedang, dan rendah serta dapat melibatkan keaktifan siswa dalam proses pembelajaran [10]. Penelitian oleh Wiwin Ambar Sari juga menyimpulkan bahwa pendektan inkuiri terbimbing yang melibatkan proses secara ilmiah melalui eksperimen untuk membuktikan kebenaran suatu materi yang dipelajari mampu 
meningkatkan keterampilan proses sains dasar pada siswa [11].

\section{SIMPULAN}

Berdasarkan hasil penelitian dan hasil pembahasan dapat disimpulkan keterampilan proses sains siswa yang menerapkan model inkuiri terbimbing dengan menggunakan laboratorium virtual lebih baik dibandingkan dengan menerapkan model inkuiri terbimbing menggunakan laboratorium riil. Hal ini disebabkan siswa yang menggunakan laboratorium real masih banyak terdapat kendala teknis yang menghambat proses percobaan, siswa masih banyak yang belum memahami cara menggunakan alat-alat laboratorium dengan benar sehingga mengakibatkan hasil percobaan menjadi tidak akurat dan waktu percobaan menjadi lebih lama. Sementara, siswa yang menggunakan laboratorium virtual tidak ditemui kendala teknis karena semua siswa sudah mempunyai basic pengoperasian komputer dengan baik, selain itu siswa dapat melakukan percobaan berulang-ulang sampai merasa paham tanpa menghabiskan waktu untuk mempersiapkan pengulangan. Besarnya pengaruh diperoleh dengan menghitung koefisien korelasi $\left(\mathrm{r}^{2}\right)$ dan peningkatan koefisien pengaruh $(\mathrm{Kp})$ didapat hasilnya sebesar $10,96 \%$.

\section{REFERENSI}

[1] W.A Sari, S. Sentosa, Maridi, Penerapan Pembelajaran Inkuiri Terbimbing Terhadap Keterampilan Proses Sains Dasar Pada Pelajaran Biologi Siswa Kelas VIII SMP Negeri 7 Surakarta, vol.5, no.1, pp 81-82, Jan, 2013.

[2] R. J Mufidah dan S. H. Syarief, Penerapan Model Pembelajaran Inkuiri Untuk Melatihkan Keterampilan Proses Pada Materi Pokok Larutan Penyangga Siswa Kelas XI SMA Mazraatul Ulum Paciran Lamongan, vol. 3, no. 2, pp.232-233, Mei 2014.

[3] A. Pujiati, Pengaruh Model Pembelajaran (Berbantuan Laboratorium Virtual) dan Minat Belajar Tehadap Kemampuan Berpikir
Kreatif Kimia, vol 2, no. 3, p.182, ISSN: 2088-351X, 2013.

[4] S. U. Rahayu. Pengaruh Media Laboratorium Virtual Dalam Pembelajaran Larutan Penyangga Terhadap Hasil Belajar Siswa Kelas XI IPA SMAN 8 Muaro Jambi, p.2, 2014.

[5] Kementerian Pendidikan dan Kebudayaan Republik Indonesia. 2013. UndangUndang Republik Indonesia Nomor 20 Tahun 2013 Tentang Sistem Pendidikan Nasional. Jakarta: Kementerian Pendidikan dan Kebudayaan.

[6] I. P. Riyadi.B. A. Prayitno, Marjono, Penerapan Model Pembelajaran Inkuiri Terbimbing (Guided Inquiry) pada Materi Sistem Koordinasi untuk Meningkatkan Keterampilan Proses Sains pada Siswa Kelas XI IPA 3 SMA Batik 2 Surakarta Tahun Pelajaran 2013/2014, vol 7, no. 2, pp.83, Mei, 2015.

[7] R. Ikayanti dan Suhartatik, Pengaruh Implementasi Model Pembelajaran Inkuiri Terbimbing Terhadap Kemampuan Pemahaman Konsep Dan Keterampilan Proses Sains Siswa Kelas IX SMPN I Lumajang, Prosiding Seminar, p.189, Mar, 2016.

[8] S. Aprilia, Pembelajaran Kimia Berbasis Masalah (Problem Based Learning) Dengan Menggunakan Laboratorium Real Dan Virtual Ditinjau Dari Gaya Belajar Siswa Di SMA Negeri 1 Boja Tahun Pelajaran 2010/2011, vol 2, no 2. p.46, Nov, 2015.

[9] Eno Lerianti. Perbandingan Hasil Belajar Dengan Menggunakan Laboratorium Nyata Dan Laboratorium Virtual Dalam Materi Asam Basa Kelas XI IPA SMA Nusantara Kota Jambi. 2014. pp.6-10.

[10] Idhun Prasetyo Riyadi, dkk. Penerapan Model Pembelajaran Inkuiri Terbimbing (Guided Inquiry) pada Materi Sistem Koordinasi untuk Meningkatkan Keterampilan Proses Sains pada Siswa Kelas XI IPA 3 SMA Batik 2 Surakarta Tahun Pelajaran 2013/2014, Jurnal, Semarang: UNS, p. 83, 2015, 
[11] Wiwin Ambar Sari, Slamet Sentosa, Maridi, Penerapan Pembelajaran

Inkuiri Terbimbing Terhadap

Keterampilan Proses Sains Dasar Pada

Pelajaran Biologi Siswa Kelas VIII SMP

Negeri 7 Surakarta, 2013, Jurnal,

Surakarta: UNS. p.93 